\title{
TRAUMATIC ULCERATIVE GRANULOMA WITH STROMAL EOSINOPHILIA - AN ORAL ULCER WITH SPECIFIC HISTOLOGY
}

\author{
P. S. Jayalakshmy' , C. R. Jyothi², P. H. Prasad ${ }^{3}$, V. V. Kamala ${ }^{4}$
}

1 Professor, Department of Pathology, Kerala University of Health Sciences, Thrissur.

${ }^{2}$ Assistant Professor, Department of Pathology, Kerala University of Health Sciences, Thrissur.

${ }^{3}$ Professor, Department of Pathology, Kerala University of Health Sciences, Thrissur.

4 Professor, Department of Pathology, Kerala University of Health Sciences, Thrissur.

\begin{abstract}
\section{BACKGROUND}

Traumatic Ulcerative Granuloma with Stromal Eosinophilia (TUGSE) is a benign, chronic self-limiting ulceration of oral cavity. Most common location is the tongue. Since the ulcer has elevated margins and indurated base, clinically it mimics squamous cell carcinoma. Biopsy interpretation is essential for any non-healing ulcer in the oral cavity. We hereby report 6 cases of Traumatic Ulcerative Granuloma with Stromal Eosinophilia diagnosed in our centre during a period of 3 years.
\end{abstract}

\section{KEYWORDS}

Non-Healing Oral Ulcer, Stromal Eosinophilia, Traumatic Ulcerative Granuloma, TUGSE, Tongue Ulcer.

HOW TO CITE THIS ARTICLE: Jayalakshmy PS, Jyothi CR, Prasad PH, et al. Traumatic ulcerative granuloma with stromal eosinophilia - an oral ulcer with specific histology. J. Evolution Med. Dent. Sci. 2017;6(2):141-143, DOI: 10.14260/Jemds/2017/34

\section{BACKGROUND}

Traumatic Ulcerative Granuloma with Stromal Eosinophilia (TUGSE) is a rapidly progressing painful lesion in oral cavity, most commonly in tongue. Other reported locations in decreasing order are cheeks, between the gum and cheek, lips, gums, palate and floor of the mouth. Exact aetiology is unknown. The patients usually give a history of trauma. Histologically, the lesion shows polymorphous population of inflammatory cells rich in eosinophils.

We report 6 cases of TUGSE diagnosed in our Institution, during a 3-year period from August 2012 to July 2015.

\section{Cases}

6 cases were diagnosed during a 3-year period from August 2012 to July 2015. The age of the patients varied from 53 to 77 years with a mean of 60.3 (Chart 1); 5 were females and one male patient (Chart 2). In all the cases, ulcer was in the tongue; 5 of them were in the posterolateral aspect of the tongue and one on the ventral surface (Chart 3 ). The size varied from 6 to $15 \mathrm{~mm}$; 4 cases were clinically diagnosed as malignant since the ulcer had an indurated base.

All cases showed ulcerated mucosa with surface fibrinoid material (Figure 1A) and a dense polymorphous cellular infiltrate involving the ulcerated epithelium, extending deeply into the underlying soft tissue and between the skeletal muscle fibres of the tongue. (Figure 1B) The infiltrate was composed of abundant eosinophils admixed with small lymphocytes, histiocytes and occasional large cells with vesicular nucleus and prominent nucleolus. (Figure 1C) Proliferating blood vessels with plump endothelial cells were distributed throughout the lesion.

Financial or Other, Competing Interest: None.

Submission 19-11-2016, Peer Review 23-12-2016,

Acceptance 29-12-2016, Published 05-01-2017.

Corresponding Author:

Dr. P. S. Jayalakshmy,

"Parijatham", Royal Avenue,

Kuttur P. O. Thrissur-680013, Kerala.

E-mail: psjayalakshmy@gmail.com

DOI: $10.14260 /$ jemds $/ 2017 / 34$
Perineural infiltrate was also seen in one case (Figure 1D). Special stains did not reveal any micro-organisms. The diagnostic features for TUGSE were seen in all the 6 cases. Details of the cases are given below.

\begin{tabular}{|c|c|c|c|c|c|}
\hline $\begin{array}{c}\text { Sl. } \\
\text { No. }\end{array}$ & $\begin{array}{c}\text { Age } \\
\text { (Years) }\end{array}$ & Sex & Site & $\begin{array}{c}\text { Size } \\
(\mathbf{m m})\end{array}$ & $\begin{array}{c}\text { Clinical } \\
\text { Diagnosis }\end{array}$ \\
\hline 1 & 53 & $\mathrm{~F}$ & $\begin{array}{c}\text { Posterolateral } \\
\text { Aspect of Tongue }\end{array}$ & 10 & Ca-Tongue \\
\hline 2 & 52 & $\mathrm{~F}$ & $\begin{array}{c}\text { Posterolateral } \\
\text { Aspect of Tongue }\end{array}$ & 12 & Ca-Tongue \\
\hline 3 & 57 & $\mathrm{~F}$ & $\begin{array}{c}\text { Posterolateral } \\
\text { Aspect of Tongue }\end{array}$ & 15 & Ulcer -Tongue \\
\hline 4 & 63 & $\mathrm{~F}$ & $\begin{array}{c}\text { Posterolateral } \\
\text { Aspect of Tongue }\end{array}$ & 10 & Traumatic Ulcer \\
\hline 5 & 77 & $\mathrm{M}$ & $\begin{array}{c}\text { Ventral Surface } \\
\text { of Tongue }\end{array}$ & 06 & Ca-Tongue \\
\hline 6 & 60 & $\mathrm{~F}$ & $\begin{array}{c}\text { Posterolateral } \\
\text { Aspect of Tongue }\end{array}$ & 12 & Ca-Tongue \\
\hline
\end{tabular}

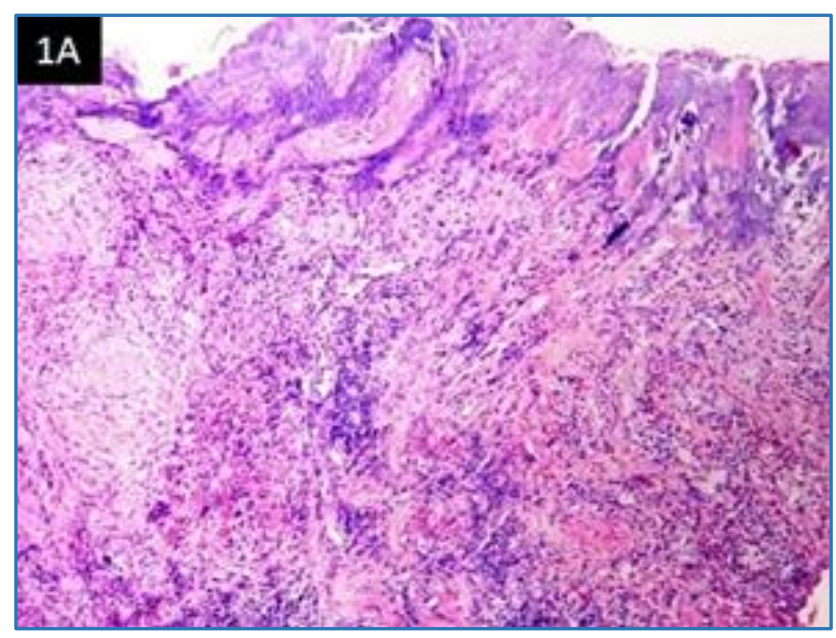

Figure 1A. Ulcerated Mucosa of Tongue (H and $E x 100)$ 


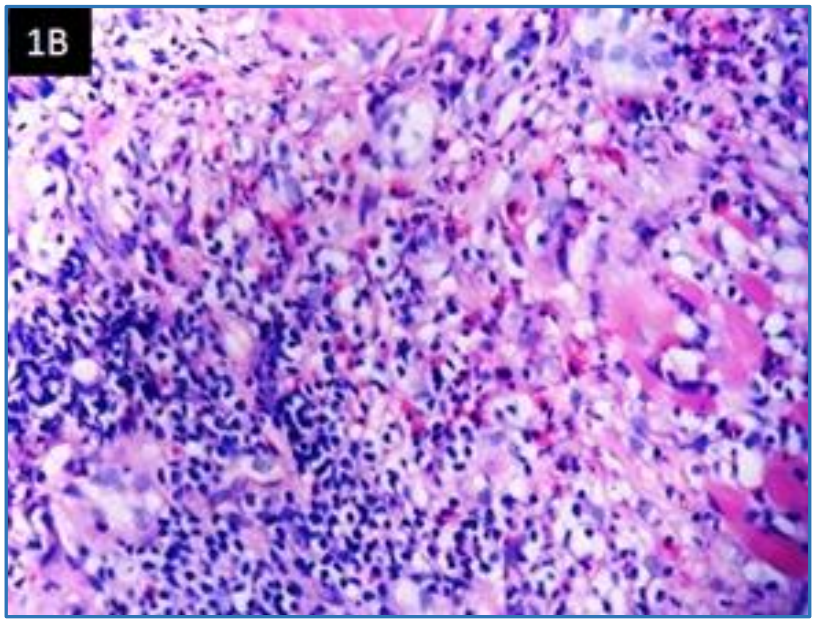

Figure 1B. Polymorphous Inflammatory Cell

Infiltrate Rich in Eosinophils Infiltrating the Muscle Tissue (H and Ex400)

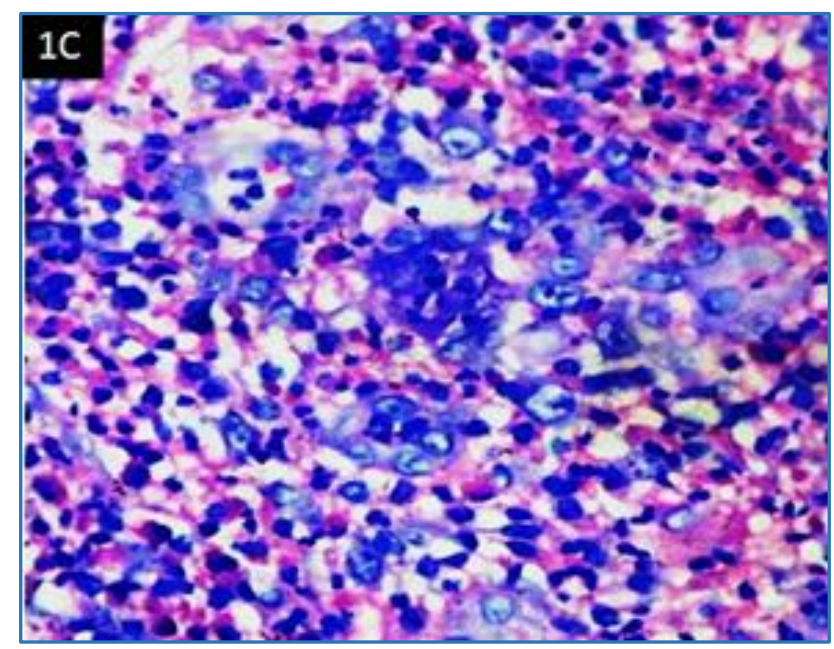

Figure 1C. Scattered Large Cells with Prominent Nucleoli (H and E x400)

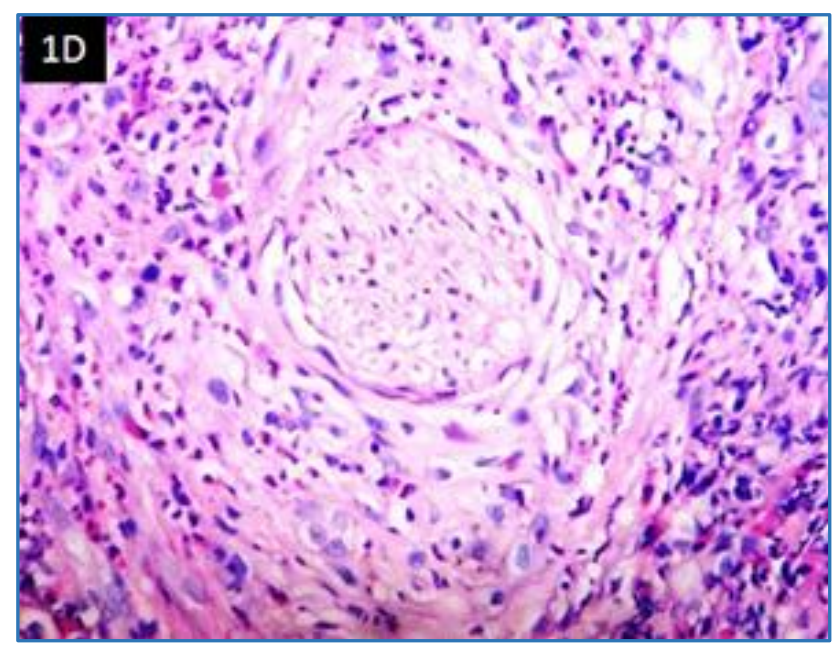

Figure 1D. Perineural Inflammatory Infiltrate (H and $E \mathrm{X} 400)$
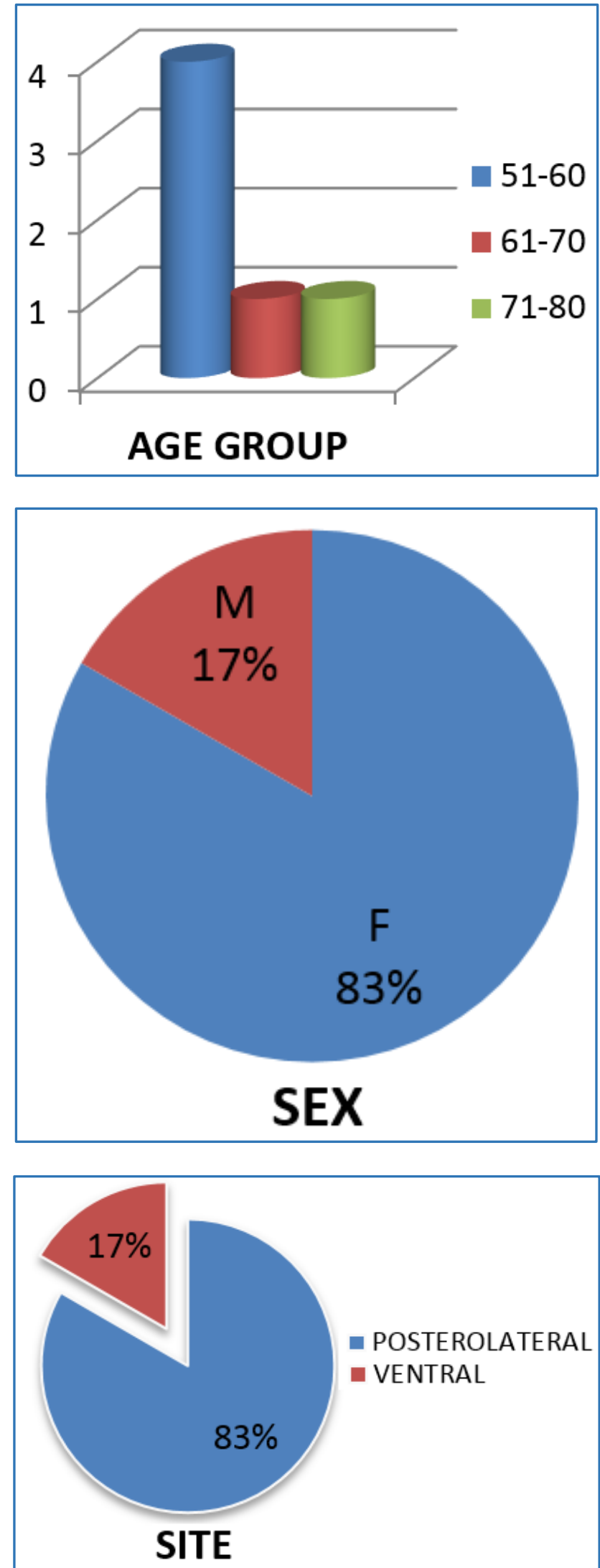

\section{DISCUSSION}

TUGSE is a solitary painful ulcer occurring in middle-aged people. In our case series, age group was more than 50 years as in many of the other studies.(1,2) An equal sex distribution was encountered in majority of the reports,(2) but in our study there was a female preponderance. All of them were otherwise healthy individuals. Definite history of trauma 
caused by a sharp denture was present in 4 cases. TUGSE has size ranging from a few $\mathrm{mm}$ to several $\mathrm{cm}$ with an indurated base showing white or yellow slough, which can be wiped off. Edge is raised and firm with surrounding redness. In our cases, size ranged from 0.6 to $1.5 \mathrm{cms}$ and the most common site was posterolateral border of tongue. In many other studies tongue was the commonest site.

Tongue and oral mucosa are common sites for traumatic ulceration, because of the nearby location of the teeth. But most traumatic oral ulcers heal rapidly and are devoid of eosinophils.

Histopathologically, TUGSE is a unique type of chronic ulceration of the oral mucosa, the diagnosis of which is based on the histologic features that include the presence of an ulcer showing polymorphous inflammatory cell infiltrate with a predominance of eosinophils. The infiltrate extends deep into the muscle tissue of the tongue. Histopathological features for diagnosis were seen in all our cases including ulceration and tissue eosinophilia. Elzay $\mathrm{RP}^{(3)}$ et al suggested that the presence of eosinophils in TUGSE may represent a tissue reaction to some unknown antigen introduced via mucosal injury. Mucosal degeneration or ulceration is a result of proliferation of cytotoxic $\mathrm{T}$ cells or toxic products released by degranulating eosinophils.(2) Occasional large cells with vesicular nucleus and prominent nucleolus were also noted as in other case reports. $(4,5)$ Study by Ficarra G et al have shown that these cells are CD30 positive and they proposed that TUGSE may be a CD30+ lymphoproliferative disorder.(4) Some authors found only vimentin positivity in these large cells and interpreted these cells as myofibroblasts.(5)

In our opinion, these CD 30 positive cells may be immunoblasts, which can be seen in any reactive lymphoid population and which also can be positive for CD30 immunostain. Along with that, there were plump endothelial cells and histiocytes which may also be misinterpreted as atypical cells. All our patients are doing well after excision of the ulcer.

Elovic AE et al demonstrated a deficiency in synthesis of transforming growth factor by eosinophils and proposed that a lack of significant synthesis of transforming growth factor by eosinophils can explain the delayed healing characteristic of TUGSE.(6)

The same entity in infants and neonates is called RIGAFEDE disease, caused by repeated trauma from a natal tooth. This was initially described by Antonio Riga in 1881(7) and F. Fede in 1890.(8) It has been later described as "Riga-Fede disease." We did not come across such a case in this age group in the present study.

\section{CONCLUSION}

TUGSE is a benign reactive ulceration of the oral mucosa with eosinophil rich inflammatory infiltrate. In many of the cases, trauma incited from sharp tooth cusp or artificial dentures is the contributing factor. Awareness and recognition of TUGSE is important because it often clinically mimics oral cancer. Tissue biopsy is essential to establish the diagnosis. In most of the cases, the lesions heal spontaneously, especially after an incision biopsy or excision of the ulcer so that there is no need for more radical surgery.

\section{REFERENCES}

[1] Hirshberg A, Amariglio N, Akrish S, et al. Traumatic ulcerative granuloma with stromal eosinophilia: a reactive lesion of oral mucosa. Am J Clin Pathol 2006;126(4):522-9.

[2] Alobeid B, Pan LX, Milligan L, et al. Eosinophil-rich CD30+ lymphoproliferative disorder of oral mucosa. A form of traumatic eosinophilic granuloma. Am J Clin Pathol 2004;121(1):43-50.

[3] Elzay RP. Traumatic ulcerative granuloma with stromal eosinophilia (Riga-Fede's disease and traumatic eosinophilic granuloma). Oral Surg Oral Med Oral Pathol 1983;55(5):497-506.

[4] Ficarra G, Prignano F, Romagnoli P. Traumatic eosinophilic granuloma of the oral mucosa: a CD30+(Ki1) lymphoproliferative disorder? Oral Oncol 1997;33(5):375-9.

[5] eI-Mofty SK, Swanson PE, Wick MR, et al. Eosinophilic ulcer of the oral mucosa. Report of 38 new cases with immunohistochemical observations. Oral Surg Oral Med Oral Pathol 1993;75(6):716-22.

[6] Elovic AE, Gallagher GT, Kabani S, et al. Lack of TGF- $\alpha$ and TGF- $\beta 1$ synthesis by human eosinophils in chronic oral ulcers. Oral Surg Oral Med Oral Pathol Oral Radiol Endod 1996;81(6):672-81.

[7] Riga A. Di una malattia della prima infanzia, Probabilmente non-trattata, di movimenti patologici. Napoli 1881.

[8] Fede F. Della produzione sottolinguale o malattia di Riga. Atto Congresso italiano di pediatria 1890. Napoli 1891:251. 